\title{
EXEMPTIONS RESULTING FROM THE INTERNATIONAL PUBLIC SECTOR ACCOUNTING STANDARDS (IPSAS) AND EUROPEAN STANDARDS FOR INTANGIBLE INVESTMENT, INVENTORIES AND PERSONNEL EXPENDITURES IN PUBLIC ENTITIES
}

\author{
Corina ENACHE \\ corina.enache2804@yahoo.com \\ “CAROL I” NATIONAL DEFENSE UNIVERSITY, BUCHAREST, RoMANIA
}

\begin{abstract}
Simultaneously with the globalization of economies, it was necessary the adoption and implementation of international accounting standards for the public sector also. In 1996 a set of accounting standards for public sector entities was developed, namely International Public Sector Accounting Standards (IPSAS). After $31^{\text {st }}$ July 1998, 32 IPSAS standards, mostly inspired by IASs, centered on model and engagement-based accounting, were issued. IPSAS 1 - Presentation of financial statements relating to the place of intangible assets, inventories and personnel expenses in the content and format of the financial statements is applied to all general purpose financial statements realized under accrual accounting. The IPSAS 12 - Inventory objective is to state the stock accounting treatment. The IPSAS 25 objective - Employee benefits is to state the employee benefits from an accounting perspective.
\end{abstract}

\section{KEYWORDS:}

International Public Sector Accounting Standards, intangible assets, stocks, human resources expenditures

\section{Introduction}

Over time, accounting has undergone numerous changes, adapting permanently to current information requirements. This area had to comply with the changes and decisions in the political, social, cultural and economic environments, thus identifying the need for the emergence of a common financial reporting system.

European Commission regulation 1606 / 2002 provides that "the adoption and application of international accounting standards in the European Union aims to harmonize the financial reporting of 
economic entities (...) in order to guarantee a high level of transparency and comparability of financial statements" (Regulation (EC) no. 1606/2002 of the European Parliament and of the Council of 19 July 2002 on the application of international accounting standards).

The International Federation of Accountants / IFAC, founded in 1977, represents the world-wide organization of accountants created with the aim of "serving the public interest, strengthening the accounting profession worldwide and contributing to the development of strong international economies by initiating and promoting accession to high quality professional standards, the process of international convergence of these standards, as well as debating issues of public interest, for which professional experience is extremely relevant" (International Federation of Accountants, 2019). Consequently, the necessity to make some changes in the public accounting system conducts to elaboration of the accounting standards for the public sector.

Concomitantly with the globalization of economies, the adoption of international accounting standards for the public sector was also required. Thus, IFAC constituted in 1995 the IPSASB / International Public Sector Accounting Standards Board, body whose purpose is to achieve high quality accounting standards, specific and applicable to the public sector worldwide. The main goal of the IPSASB is "to facilitate the exchange of information between public accounting professionals, to respond to the needs of national or local organizations, to promote educational or research programs in the public domain" (International Public Sector Accounting Standards Board, 2019). In 1996, IFAC has elaborated another set of international accounting standards for public sector, namely IPSAS.

Since 2005 IPSAS have been applied at the level of the European Union for its own accounting, as well as at the level of other organizations, such as the United
Nations / UN, the Organization for Economic Cooperation and Development / OECD or the North Atlantic Treaty Organization / NATO. Also, the World Bank and the International Monetary Fund have recommended the countries under influence to adopt IPSAS standards. Due to the fact that neither IPSASB nor the accounting profession can impose IPSAS standards, the final decision for adoption and application is up to each country.

And our country as a NATO and EU member has aligned itself with the international effort to adapt its accounting system to that of the partner countries. Thus, in the accounting system of our country, numerous modifications of the accounting regulations have been adopted in the effort to implement IFRS and IPSAS standards. This represented a considerable effort as the accounting process had to be changed, new accounting policies and practices being implemented in order to align with the international provisions in the field.

2. General aspects regarding international public sector accounting standards / IPSAS and european standards in the field for non-current assets, inventories and personnel expenses in public entities

The geopolitical context in which our country was at the beginning of the $21^{\text {st }}$ century has forced Romania to join international organizations that ensure both the security, independence and sovereignty of the country, but also its economic stability. Thus, following Romania's accession to the North Atlantic / NATO Organization in 2004 and to the European Union in 2007, measures were needed to modernize and reform the public sector in Romania, a sector that had to be aligned with the new requirements specific to the two blocks / alliances in which our country has been integrated.

Part of this effort, we find also the process of aligning the accounting system 
in the Romanian public sector to the international requirements specific to the European allies and partners, which was a large process with a complex character through the diversity of the fields in which the introduction of novelty elements was required. This process had begun beforehand, following the aspirations and the new postrevolutionary orientations of the Romanian society since 1991, the Accounting Law no. 82 for companies, banks, insurance companies, public institutions, etc.

As presented above, in 1996, IFAC initiated a new project in order to develop accounting standards for public sector entities, known as IPSAS.

As of July 31, 1998, 32 IPSAS standards were issued, most of them inspired by IAS, focused on model and commitment based accounting.

In our country, in the Government Action Plan for 2000-2004 we can find the idea to reorganize the public sector through:

a) improving the budget classification;

b) prioritizing the economic classification and the functional classification from an institutional point of view;

c) the supplement to the cash accounting commitment commitments.

Starting with 2000, the Government of Romania has initiated a program for restructuring the public sector, but in concrete these changes are only implemented since 2003 by implementing laws, orders and provisions. The reform of the public sector supposed three major stages, namely:

a) stage $1-\mathrm{O}$ rder of the Minister of Public Finance no. 1746 / 2002 by which are approved the methodological norms of organizing and conducting the accounting of the public institutions' patrimony, of the Accounts Plan for public institutions and of the Monograph regarding the recording in accounting of the main operations. These stipulations were available for 13 authorizing officers experienced since the first half of 2003, in the same time with the current regulations, and from January 1, 2004, they apply to each public institution. b) stage 2 - Government Ordinance no. $81 / 2003$ and the Order of the Minister of Public Finance no. 1487 / 2003 regarding the reassessment and amortization of fixed assets in the patrimony of public institutions;

- Order of the Minister of Public Finance no 520/2003 approving the methodological norms regarding the organizing and conducting the budgetary revenue accounting.

c) Stage 3 - Order of the Minister of Public Finance no 1025/2005 introduces a new budget classification, applicable from 2006 to comply with the requirements of the European System of Accounts ESA 95 regarding the elaboration and presentation by the international bodies of statistics on public finances with the purpose to enhance the organization and transparency of operations with public funds and the implementation of public finances of the Schengen Community;

- The Order of the Minister of Public Finance no 1917/2005 marks the transition from the cash accounting system to the commitment accounting system starting with January 1, 2006.

"The introduction of commitment accounting at the expense of cash accounting at the public sector level is one of the initial and most important steps in the process of reforming public financial management. In this context, IPSAS becomes an international benchmark in terms of public sector financial information based on commitment accounting. The adoption of IPSAS by several international bodies and supranational institutions contributes to their legitimacy, especially given the fact that this process has an impact on the implementation of IPSAS in the Member States of the European Union" (Brusca, Gómez-Villegas \& Montesinos, 2016, pp. 51-64).

At present, specific to the public sector, a number of 32 IPSAS standards have been adopted based on IFRS standards 
(IPSAS 1-21, 25-31), own standards have been developed for the particular field of the public sector (IPSAS 22, 23, 24, 32) and, at the same time, a financial reporting standard was developed based on cash accounting. Periodically, the standards are updated according to changes in IFRSs or changes in the public sector.

3. Implementation of IPSAS 1 presentation of financial statements regarding the place of non-current assets, inventories and expenditures with personnel

Regarding the implementation of IPSAS 1 - Presentation of the financial statements regarding the place of noncurrent assets, inventories and expenditures with the staff in the content and format of the financial statements, we want to clarify certain specific issues.

Accounting provides information for all categories of users, external and internal, information on which they base their decisions on the allocation of funds.

Studying and analyzing IPSAS, I consider that it is necessary to apply this standard to all general purpose financial statements in accordance with accrual accounting.

As we find in the literature, "financial statements are a structured representation of the financial position and financial performance of an entity, whether it is public, private or non-profit" (International Public Sector Accounting Standards (IPSAS), 2012).

Generally, financial statements include data on financial performance, financial position, changes in net assets / equity, cash flows, a summary of conclusive accounting policies, and when the entity to ensure transparency is made public the approved budget, a comparative analysis of the budgetary values with the real ones, as well as other explanatory notes.

To achieve these goals, the financial statements provide information on:
a) assets;
b) debts;
c) net assets / equity and other changes of them;

d) revenues;

e) expenditures;

f) cash flows.

The need to satisfy the general and detailed information needs of the two categories of information beneficiaries has led to the separation of accounting into two parts. For accounting in Romania, at the level of patrimonial entities there are two sections of accounting, financial and management.

While financial accounting ensures the production of financial statements by providing specific details regarding financial position, financial performance and cash flows for both the requirements of the institution and for external users, management accounting provides accounting information that is quantified and processed by the entity's managers.

\section{IPSAS 12 - Inventories}

Regarding inventories, we would like to pay attention to IPSAS 12 - Inventories whose objective is "to prescribe the accounting treatment for stocks. A fundamental problem in the accounting of inventories is the value of the cost to be recognized as an asset and carried forward until the related revenues are recognized. This standard provides guidance on cost determination and its subsequent recognition as an expense, including any reduction in net realizable value. The standard also provides guidance on cost determination formulas that are used to calculate inventory costs" (IFAC, 2012, p. 385).

Inventories are "current assets: held for sale during the normal course of business; under production for sale after completion; or in the form of raw materials, consumables to be used in the production process or for the provision of services" (Achim, 2019, p. 3).

In the category of inventories we find the goods bought and held for sale, 
including goods, land and properties kept for sale. Also, inventories include finite products made or production in progress.

Moreover, we find the following goods in this category: materials and consumables which will be used in the production process, as well as goods purchased or produced by the entity in order to be delivered to third parties free of charge or for a specified price.

Within the public sector, in the category of inventories we can meet: ammunition, consumables, spare parts for other tangible assets than those dealt with in the standards on tangible assets, strategic provisions (for example, energy reserves), maintenance materials, non-cash money stocks, postal stocks held for sale (eg stamps) and products in progress.

Depending on when and where they appear, inventories fall into three categories:

a) inventories for the production process, of which raw materials, consumables, inventory items, state reserve materials, etc. are included;

b) inventories obtained during the production process, such as production in progress, semi-finished products, finished products, residual products;

c) inventories in units or outlets, such as goods and packaging.

Good inventories management requires that: the nature of the goods be accurately indicated, the entry into stock is recorded at the time of ownership transfer, the valuation of the inflows and outflows of goods in and out of the stock be accurately defined and remain unchanged.

This standard shall "not apply to the assessment of inventories held by producers of agricultural and forestry products, of agricultural products after harvesting and of minerals and other mineral products, to the extent that they are measured at net realizable value in accordance with the well-established practices of those sectors of activity and broker-dealers from the inventories exchange that assess their inventories at fair value, minus the costs generated by selling" (Morariu, 2012, p. 16).

IPSAS 12 applies to all entities in the public sector, with the exception of state economic entities (which apply the IFRSs issued by the IASB).

\section{IPSAS 25 - employee benefits}

By studying and analyzing the main provisions of international accounting standards, we will identify human resources expenditures as a category of expenses that can be found in the financial performance of a public entity.

The purpose of this standard is "to prescribe accounting and information disclosure for employee benefits. The standard requires an entity to recognize:

a) a debt when an employee has rendered services in exchange for the benefits to be paid in the future;

b) an expense when the entity consumes the economic benefits or the potential of services that arise as a result of the service provided by an employee in exchange for benefits" (IFAC, 2013, p. 862).

This standard is applied by the employer for accounting all the employee benefits, except for share-based transactions (checked the relevant international or national accounting standard that deals with share-based transactions).

Employee benefits include:

"a) the benefits of short-term employees, such as weekly remuneration, salaries and social security contributions, paid annual leave and paid medical leave, participation in profit and bonuses (if paid within twelve months of the end of the period), as well as non-monetary benefits (such as healthcare, accommodation, cars, as well as free or subsidized goods or services) for current employees;

b) post-employment benefits, such as pensions, other retirement benefits, postemployment life insurance and postemployment health care;

c) other long-term employee benefits, including sabbatical days, jubilees or other 
benefits arising from seniority, long-term incapacity benefits and, if not paid in full within twelve months of the end the period, participation in profits, bonuses and deferred compensation;

d) benefits for terminating the employment contract" (National Securities Commission, 2011).

Also, the short-term employee benefits include "elements such as:

a) weekly remuneration, salaries and social security contributions;

b) short-term absences compensated (such as paid annual leave and paid medical leave) in which the compensation for absences is to be settled within twelve months from the end of the period in which the employees provide the service in question;

c) the bonuses related to the performance and the participation in the profit to be paid within twelve months after the end of the period in which the employees provide the service in question;

d) non-monetary benefits (such as healthcare, accommodation, cars and free or subsidized goods or services) for current employees" (IFAC, 2013).

The size of the expenditures with human resources to different public entities will influence inversely proportional the period surplus or deficit in the sense that spending with large human resources leads to diminishing the surplus or increasing the deficit of the period and conversely, spending with small human resources generates the increase of the surplus or the reduction of the deficit period.

\section{Conclusions}

Adopting IPSAS standards presents a number of advantages such as the following: the quality of financial reporting by public institutions and also the credibility and transparency of the information presented were significally increased; more efficient internal control and more transparency of assets and liabilities, more detailed information on useful costs in support of results-based management, more complete information that supports resource management and management, providing effective benefits and achieving results, assessment of responsibility at the level of all resources that the public institution manages, decision making regarding the provision of resources or development of new activities, evaluation of the financial situation, performance and cash flows of public institutions, as well as greater coherence and better comparability of financial statements.

Also, the full application of these standards in our country should be taken into account by the experience of other European countries and from the world that have already achieved this. Indeed, many countries, even if they have implemented the IPSAS standards, they have not received certification for their accounts from the external audit, because they did applied just a parts of the IPSAS' requirements taking into consideration that they had deficiencies of the internal control and the information system. 


\section{REFERENCES}

Achim, S. (2019). Basis of Accounting (course). p. 3, available at: https://econ.ubbcluj.ro/ victor.muller/Download/BC/Diverse/Conta $\% 20$ angajamente $\% 20$ si $\%$ 20Rec $\% 20$ si $\% 20$ eval $\% 20$ elementelor $\% 20$ poz $\% 20$ fin $\% 20$ si $\% 20$ perform.doc, accessed on 10 October 2019.

Brusca, I., Gómez-Villegas, M., \& Montesinos, V. (2016). Public Financial Management Reforms: The Role of IPSAS in Latin-America. Public Administration and Development, Vol. 36, No. 1, 51-64.

European Parliament \& Council of the European Union. (2002). Regulation (EC) no. 1606/2002 of the European Parliament and of the Council of 19 July 2002 on the application of international accounting standards.

International Federation of Accountants (IFAC). (2013). Handbook of IPSAS norms. Vol.1, translated and republished by The Body of Accountants Experts and Authorized Accountants from Romania, Bucharest.

International Federation of Accountants. (2019). available at: https://www.ifac.org/about-ifac, accessed on 12 October 2019.

International Public Sector Accounting Standards (IPSAS). (2012). Changes of IAS 1 Presentation of financial statements. Commission Regulation (EU) no. 475/2012, Bruxelles: Official Journal of the European Union, no. 6 / 5 June 2012.

International Public Sector Accounting Standards Board. (2019). available at: https://www.ipsasb.org, accessed on 10 September 2019.

Morariu, A. (2012). IAS 2 Inventories, Convergences and divergences between IAS 2 and the National Norm (OMFP 3055/2009), Bucharest.

National Securities Commission. (2011). Regulation of the National Securities Commission no. 3 / 2011 on the Accounting Regulations in compliance with the VII Directive of the European Economic Communities applicable to the entities authorized, regulated and supervised by the National Securities Commission. Bucharest: Official Gazette, no. 156 / 3 March 2011.

Romanian Parliament. (1991). Law no. 82/1991 - Law on Accounting, republished. Bucharest: Official Gazette. no. 454 / 18 June 2008. 